\title{
A CURA INTERIOR NO CATOLICISMO CARISMÁTICO: TECNOLOGIAS DE SI E PSICOLOGIZAÇÃO DA RELIGIÃO
}

Emerson José Sena da Silveira

Resumo: O catolicismo carismático brasileiro, ao dialogar com as contemporâneas transformações da identidade e da sociedade, produziu uma prática chamada cura interior ou "cura das memórias e emoções". Como experiência religiosa, a cura interior expande-se em três segmentos: comunidades carismáticas de vida e aliança, grupos e "flutuantes" (praticantes desvinculados de grupos e comunidades). Sua prática é efetivada pelos "especialistas da cura", indivíduos que a exercem nos grupos e a aplicam às pessoas que demandam por cura. No ritual da cura interior, ocorre a produção de uma tecnologia de constituição do sujeito (tecnologia de si) em que a transferência e expansão semântica de termos e procedimentos da psicologia junguiana (e outras), da medicina e da tradição católica instituem um "fluxo intersubjetivo", transversal e simétrico, de um fazer-saber simultaneamente terapêutico e religioso. A cura interior praticada pelos "especialistas da cura" torna-se um campo no qual tendências contraditórias (busca de si e rendição ao (o)Outro) dialogam entre si. Um diálogo que tem como palco a trajetória, a memória e as emoções dos praticantes, apontando para novas formas de articulação entre as pequenas narrativas biográficas (pontuais) e as grandes narrativas da religiosidade católica (difusas e míticas).

Palavras-chave : Cura interior, Tecnologias de si, Práticas terapêutico-religiosas, Ritual.

\begin{abstract}
When it comes to take part in a dialogue with contemporaneous changes of identity and society, brazilian charismatic Catholicism puts into practice the internal cure or "cure of memories and emotions". The internal cure ritual produces the individual creation technology (self technology) where transfer and semantical expansion of terms and procedures at Jungian psychology (and others), medicine and catholic tradition builts an "intersubjective flow", transversal and symmetrical, to understand, simultaneously, therapeutic and religious. Internal cure provided by "cure specialists" becomes a field where conflicting inclinations (self search and surrender to the other) dialogues among themselves. As a religious experience, internal cure spreads into three sections: life and union charismatic communities, groups and "undefined" (practitioners separated from groups and communities). Internal cure practice is performed by "cure specialists" putting into practice and applying it towards people who demands for cure. A dialogue which has the course, memories and practitioners emotions as a stage, aiming to a new articulation between a small biographical descriptions (specifics) and a great catholic religiosity descriptions (dispersed and mythical).
\end{abstract}

Keywords: Internal cure, Self Technologies, Therapeutic-religious practices, Ritual. 